\title{
Penerjemahan Harfiah: Dominasi Dalam Teknik Penerjemahan Surat Informal
}

\begin{tabular}{ccc} 
& \begin{tabular}{c} 
Arif Hidayat \\
STMIK Nusa Mandiri \\
\\
\cline { 2 - 3 } arif.aft@ @usamandiri.ac.id
\end{tabular} & \\
\hline Diterima & Direvisi & Disetujui \\
$05-02-2020$ & $23-02-2020$ & $27-02-2020$ \\
\hline
\end{tabular}

\begin{abstract}
Translation techniques are expected to be solutions to cope with translation problems faced by translators. Due to this reason, translation learners are taught these techniques to be their provision in handling translation problems they will face as professional translators. This research is aimed at giving comprehension of the using translation techniques tendency in informal letter translation. Case study method is used in this research to analyze how English Letters students who have learnt translation through qualitative approach and document data collecting technique. This research uses Molina \& Albir's (2002)Translation Techniques to identify the translation technniques used by the students. The result shows that the dominance of literal translation technique by a very significant data finding from the eleven techniques used with normal distribution ranging from 17 until 27 data per students. The limitation of this research is on the private letter which is tight to formal language and rarely gets attention on translation study. In the next research, it is hoped that there will be wider scope of study to analyze the trends of translation techniques in those students' affiliation.
\end{abstract}

Keywords: Literal Translation, Teknik Penerjemahan, Informal Letter

\begin{abstract}
Abstrak- Teknik penerjemahan diharapkan dapat menjadi solusi dari masalah penerjemahan yang dihadapi para penerjemah. Oleh karena itu, para pembelajar penerjemahan diberikan materi teknik penerjemahan sebagai bekal untuk dapat mengatasi masalah-masalah dalam penerjemahan. Penelitian ini bertujuan untuk membuka pemahaman mengenai kecenderugan penggunaan teknik penerjemahan dalam terjemahan surat informal. Metode studi kasus digunakan untuk melihat penggunaan teknk penerjemahan yang dilakukan oleh para mahasiswa yang telah mendapat materi penerjemahan dengan pendekatan kualitatif dan teknik pengumpulan data secara dokumen. Peneliti menggunakan delapan belas Teknik Penerjemahan milik Molina \& Albir (2002) untuk mengidentifikasi jenis teknik penerjemahan yang digunakan oleh para mahasiswa. Hasil penelitian menunjukkan kecenderungan dominasi teknik penerjemahan harfiah yang digunakan mahasiswa dari sebelas teknik penerjemahan yang ditemukan dengan distribusi normal antara 17-27 data yang tersebar. Limitasi dalam penelitian ini ada pada penerjemahan surat pribadi yang tidak terikat pada bahasa formal dan jarang mendapatkan perhatian dalam penelitian penerjemahan. Dalam penelitian selanjutnya, diharapkan adanya penelitian lebih lanjut dengan ruang lingkup lebih luas dari keseluruhan penerjemah yang berada dalam satu lingkup institusi pendidikan yang mempelajari penerjemahan.
\end{abstract}

Kata Kunci: Penerjemahan Harfiah, Teknik Penerjemahan, Surat Informal

\section{PENDAHULUAN}

Penerjemahan sudah menjadi suatu kegiatan yang rutin berjalan seiring dengan percampuran budaya dan penyebaran ilmu pengetahuan dari satu negara ke negara yang lain. Kegiatan bertukar informasi dalam bentuk tulisan ini tentunya merupakan sarana penerjemahan dalam menjembatani kegiatan tersebut. Setiap penerjemahan memiliki fungsi dan tujuan sesuai dengan teks sumber yang diterjemahkan. Meskipun demikian, dalam prosesnya, penerjemah memiliki keterlibatan dalam hasil karya terjemahannya. Keterlibatan tersebut dapat dilihat dari pembaca sasaran, keterbacaan dan berbagai macam pertimbangan tujuan dari karya terjemahan tersebut sehingga karya penerjemahan dapat dikatakan sebagai penuilsan ulang sebuah karya (Lafevere dalam Gentzler, 2004; Shuping, 2013).

Proses penerjemahan sendiri tentunya menjadi sebuah proses kognitif. Basnett (2002) menyatakan bahwa penerjemah sebuah proses decoding dan recoding dengan tahapan proses penerjemahan yang dimiliki Nida sebagai berikut:

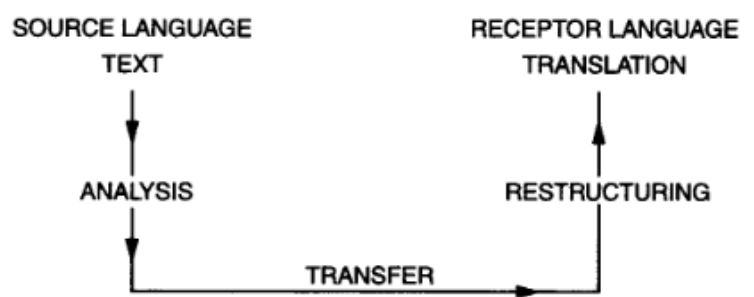


Bagan 1. Tahapan Proses Terjemahan Nida Kegiatan mendistribusikan informasi ini dapat menjadi beberapa definisi dari para ahli di bidang Studi Penerjemahan dari berbagai sudut pandang. Sebagai contoh, ada yang memandang penerjemahan sebagai kegiatan mengubah tanda (Oettinger, 1960), merubah teks atau materi teks (Catford, 1965; Wills, 1977; Hoed dalam Hidayat \& Harmoko, 2018) atau memandang pada kedekatan padanannya (Koller dalam Nida \& Taber, 1969; Nord, 2007). Unsur penyampaian pesan tetap menjadi hal utama dalam kegiatan penerjemahan.

Dalam proses penerjemahan kesepadanan menjadi hal penting dalam proses dan hasil penerjemahan. Para ahli penerjemahan memiliki pandangan masing -masing mengenai penerjemahan. Bell, Halliday dan Newmark (dalam Mujiyanto, 2011) memberikan tanggapan masing-masing mengenai kesepadanan. Bell menitikberatkan kesepadanan pada makna semantic yang terbebas dari konteks dengan mengorbankan nilai komunikatif dari konformitasi konteks atau fungsional. Di lain sisi, Halliday menyatakan bahwa penerjemahan yang bai dari suatu teks merupaan hasi; dari penerjemahan yang tekait dengan fitur-fitur kebahasaan yang memberikan atensi besar pada konteks penerjemahan dan dapat menyesuaikan dengan nilai-nilai yang tekandung dalam teks sumber. Menanggapi apa yang disampaikan Halliday, Newmark justru lebih mementingkan pemilihan bahasa untuk mengungkapkan makna sehingga pemilihan tersebut menjadi bagian yang penting dalam penerjemahan teks.

Banyak penelitian mengenai penerjemahan telah dilakukan, baik analisis terjemahan yang dilakukan oleh para ahli penerjemahan hingga yang bukan ahlinya. Penelitian mengenai terjemahan yang dilakukan oleh yang bukan ahlinya menjadi menarik karena kita dapat mengetahui bagaimana para penerjemah tersebut melakukan serangkaian metode, strategi dan teknik penerjemahan. Meskipun mereka tidak mempelajari bagaimana menerjemahkan sesuai yang diajarkan di dalam kelas seperti biasanya dilakukan para pembelajar bahasa asing, namun banyak dari penerjemahan mereka yang berterima dan dinikmati para pembacanya. Salah satu penelitian yang dilakukan adalah penelitian yang dilakukan oleh Rahma, Kristina, \& Marmanto (2018) mengenai penerjemahan sulih teks dalam bahasa Jawa Mataraman dari film Batman.

Pilihan sumber data teks sumber (TSu) berasal dari surat informal atau surat pribadi karena surat pribadi akan membuat para penerjemah tidak tertekan dengan surat formal yang harus resmi dan tidak seperti surat bisnis yang sangat resmi (Zhang, 2011). Hal ini juga menjadi salah satu dari ciri surat informal atau surat pribadi yang mengedepankan keramahan, mudah menjadi bahan obrolan, dan santai dengan suasana informal yang biasanya ditujukan pada orang-orang yang dekat dengan pengirim surat (JCPS, 2006). Selain itu, belum banyak ditemukan penelitian mengenai penerjemahan untuk surat pribadi.

\section{METODE PENELITIAN}

Metode studi kasus digunakan dalam penelitian ini karena penelitian ini berfokus pada satu kasus penerjemahan yang ada pada satu populasi, yaitu para mahasiswa Kelasa 33.7B.02 Program Studi Sastra Inggris, Fakultas Bahasa dan Seni, Universitas Bina Sarana Informatika yang telah mendapatkan mata kuliah 'Translation'. Sedangkan pembatasan dalam penelitian ini hanya pada hasil terjemahan yang dilakukan oleh para mahasiswa tersebut yang dapat dikategorikan sebagai penerjemah amatir terutama pada teknik penerjemahan yang telah mereka lakukan.

Pada penelitian ini, pendekatan kualitatif dipakai karena data yang dipakai berupa kalimat dan katakata. Sedangkan teknik pengumpulan data yang digunakan adalah studi pustaka untuk mencari data primer untuk teks sumber (TSu) yang akan diterjemahkan para mahasiswa dan data sekunder yang dipakai untuk menganalisis data. Sedangkan dokumen digunakan untuk penarikan data primer. Penulis mendapatkan Teks Sumber (TSu) secara daring dan data Teks Sasaran (TSa) dari hasil terjemahan mahasiswa atas TSu yang telah dilakukan oleh para mahasiswa atas permintaan dari peneliti. TSu dan TSa tersebut merupakan sumber data. Sedangkan data dalam penelitian ini adalah semua kata, frasa dan/atau kalimat dari TSa. Metode analisis deskriptif adalah metode analisis yang penulis pakai dengan menganalisis data-data dari bahan yang diteliti dan kemudian menjabarkan hasilnya secara deskriptif.

Untuk membantu mengolah data yang ada, teori Molina dan Albir (2002) digunakan sebagai dasar untuk melihat teknik terjemahan yang dilakukan oleh para mahasiswa. Terdapat 18 jenis teknik penerjemahan yang diutarakan oleh mereka: adaptasi, amplifikasi pinjaman, kalke, kompensasi, deskripsi, kreasi diskursif, padanan baku, generalisasi, amplifikasi linguistik, kompresi linguistik, penerjemahan harfiah, modulasi, partikularisasi, reduksi, substitusi, transposisi dan variasi.

Teori tersebut menjadi alat ukur untuk mengidentifikasi jenis teknik yang digunakan oleh para mahasiswa dalam menerjemahkan surat yang diberikan dalam bahasa Inggris. Data yang sudah 
diolah kemudian akan diterjemahkan ke dalam temuan dan pembahasan dengan penggambaran dan diberikan kesimpulan.

\section{HASIL PENELITIAN DAN DISKUSI}

\section{Hasil Penelitian}

Dari 16 Kalimat yang terdapat dalam teks sumber, didapat 209 data terindikasi menggunakan teknik yang diungkapkan oleh Mollina dan Albir (2002). Hasil penelitian menunjukkan bahwa terdapat 11 teknik penerjemahan yang digunakan oleh para mahasiswa, yaitu:
a. Amplifikasi
b. Kreasi diskursif
c. Padanan baku
d. Generalisasi
e. Amplifikasi linguistik
f. Kompresi linguistik
g. Penerjemahan harfiah
h. Modulasi
i. Reduksi
j. Transposisi
k. Variasi

Distribusi dalam penelitian ini menunjukkan distribusi normal dalam kisaran 17 hingga 27 data.

Teknik yang paling banyak digunakan adalah teknik penerjemahan secara harfiah dengan total pemakaian mencapai 79 kali ataru $37.80 \%$ secara keseluruhan. Hampir semua mahasiswa di populasi menggunakan teknik ini sebagai teknik yang paling sering mereka gunakan. Hanya 1 orang yang tidak menjadikannya teknik utama dalam terjemahan mereka. Sedangkan amplifikasi dan generalisasi merupakan teknik yang paling jarang digunakan. Hanya terdapat masing-masing $1.44 \%$ dari total 209 data yang ada. Hasil ini dapat dilihat dari pie chart berikut:

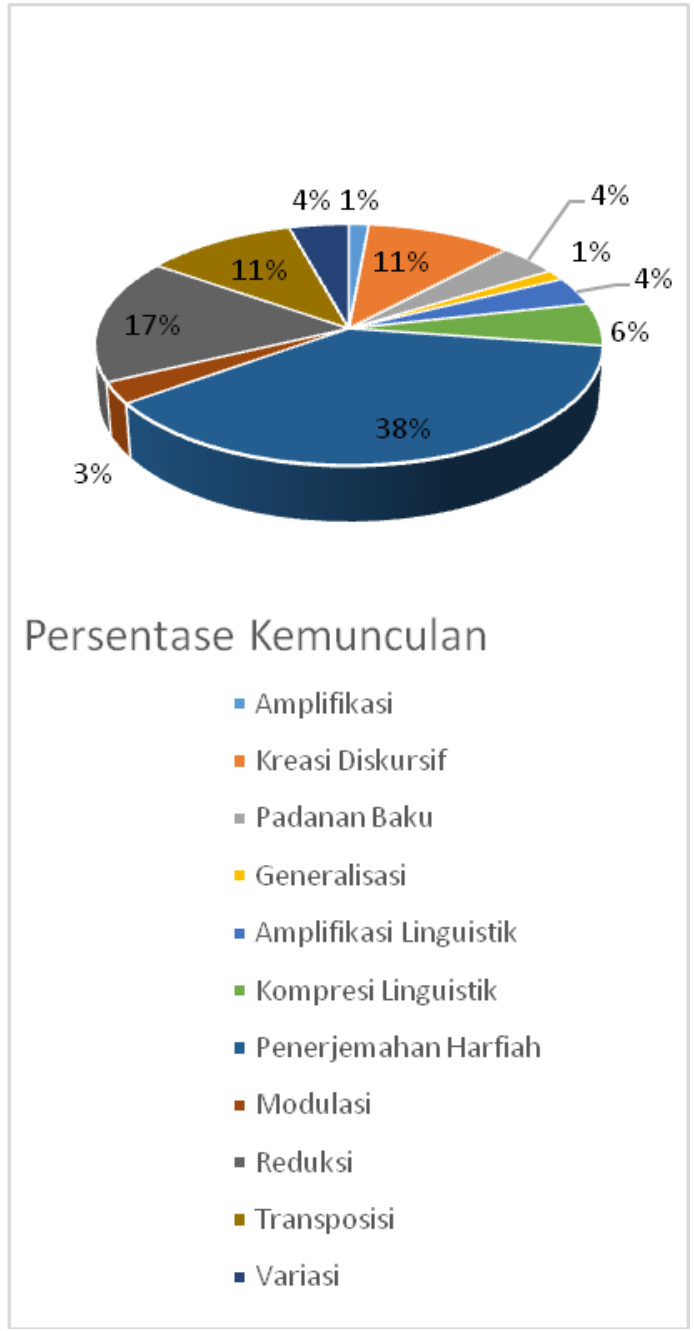

Diagram 1. Presentase Kemunculan Teknik Penerjemahan

\section{Diskusi}

Pada penelitian ini, terdapat tiga hal yang menjadi perhatian, yaitu dominasi penerjemahan harfiah dalam teknik penerjemahan dan distribusi teknik penerjemahan yang muncul dalam terjemahan yang dilakukan oleh populasi yang terdiri atas para mahasiswa kelas 33.7B.03 Program Studi Bahasa Inggris, Fakulats Bahasa dan Komunikasi, Universitas Bina Sarana Informatika.

\section{a. Teknik Penerjemahan Harfiah}

Seperti dikemukakan dalam hasil temuan penelitian di atas, penerjemahan harfiah merupakan teknik penerjemahan yang mendominasi dalam hasil terjemahan para mahasiswa kelas 33.7B.02 yang menjadi populasi.

Literal Translation atau penerjemahan harfiah merupakan teknik penerjemahan yang menerjemahkan kalimat atau ungkapan dengan kata 
per kata. Berlawanan dengan 'definisi' harfiah dari karya Stylistique comparée $d u$ français et de l'anglais (SCFA) milik Vinay dan Darbelnet, harfiah di sini bukan berarti menerjemahkan satu kata dengan kata lain. Menerjemahkan ink (bahasa Inggris) dengan incre (bahasa Perancis) bukanlah penerjemahan harfiah tapi padanan baku atau established equivalent. Penerjemahan harfiah di sini berkorespondensi dengan 'padanan formal' dari Nida, yaitu saat bentuk berpapasan dengan fungsi dan makna. Jenis ini sama dengan penerjemahan literal dari SCFA. Contoh dari teknik ini adalah terjemahan berikut:

SL: Only I didn't know what it was exactly that I was searching.

TL: Hanya aku tidak mengetahui apa yang tepatnya aku cari.

Pada contoh di atas, salah satu mahasiswa sebagai penerjemah melakukan teknik penerjemahan harfiah karena kalimat TSu diterjemahkan kata per kata olehnya. Tidak ada perubahan letak kata, reduksi maupun teknik lain yang dia gunakan. Data seperti ini banyak ditemukan dalam hasil terjemahan para mahasiswa dalam populasi, seperti contoh lain di bawah ini:

SL: Please take me up, my fiery angel, my beloved...

TL:Tolong bawa aku, malaikat berapiku, Kesayanganku...

Terlihat pada contoh di atas, penerjemah melakukan penerjemahan kata per kata, hingga bahkan frasa my fiery angel diterjemahkan 'malaikat berapiku' tanpa memaknainya secara romantic sesuai dengan konteksnya sebagai surat cinta.

\section{b. Teknik Amplifikasi}

Teknik amplifikasi adalah teknik yang hanya ditemukan sekali dalam penelitian ini. Teknik ini mengenalkan rincian yang tidak diformulasikan pada teks sumber: informasi, parafrasa eksplikatif. Korespondensinya adalah dengan:

1)Eksplisitasi milik SCFA

2) Addition dari Delisle

3) Legitimate dan ilegitimate dari Margot

4)Parafrasa eksplisit milik Newmark

5) Perifrasi dan parafrasa dari Delisle

Footnote atau catatan kaki adalah salah satu jenis dari amplifikasi. Amplifikasi merupakan kebalikan dari reduksi. Contoh dari amplifikasi adalah sebagai berikut:
TSu: Please take me up, my fiery angel, my beloved...

TSa: Tolong bawalah aku, malaikat pelitaku, kamu yang aku cinta...

Pada bagian terjemahan dari my beloved, penerjemahan memperikan tambahan pronominal 'kamu' sebagai menjelas bahwa 'kamu'lah orang yang dicintainya.

\section{c. Teknik Kreasi Diskursif}

Discursive Creation atau Kreasi Diskursif: Kreasi diskursif ini mirip dengan proposal milik Delisle, yaitu membuat padanan temporer yang secara tidak terduga sangat keluar konteks. Contoh dari diskursif ini adalah terjemahan dari Goblet of Fire yang diterjemahkan menjadi 'piala api'. Dalam penelitian ini, terdapat 22 data yang termasuk dalam kategori teknik kreasi diskursif. Contoh dari teknik ini yang ditemukan dari objek penelitian adalah sebagai berikut:

TSu: ... Like two angels caught in a cosmic embrace.

TSa: ...bagaikan dua malaikat yang menyambut surya.

Jika diterjemahkan secara harfiah ...caught in a cosmic embrace seharusnya diterjemahkan dengan 'terperangkap dalam sebuah rangkulan kosmik'. Alih-alih menerjemahkannya seperti itu, penerjemah merubahnya menjadi 'yang menyambut surya' yang di luar dari konteks makna terjemahan harfiahnya.

\section{d. Teknik Padanan Baku}

Sebanyak sembilan data yang dikategorikan sebagai teknik padanan baku atau sejumlah $4.31 \%$ dari keseluruhan data yang ditemukan, Estabished Equivalent atau padanan baku merupakan teknik menerjemahkan yang menggunakan satu istilah atau ungkapan yang sudah diakui (oleh kamus atau bahasa yang digunakan) sebagai padanan dalam bahasa sasaran. Hal ini berkorespondensi dengan penerjemahan padanan dan literal SCFA. Contoh dari teknik ini adalah terjemahan baku dari human rights yang secara baku diterjemahkan sebagai 'hak asasi manusia'

Contoh dari teknik ini adalah sebagai berikut:

TSu: Please stay by my side...

TSa: Kumohon tetaplah di sisiku... 
Dalam contoh di atas, terjemahan baku istilah atau frasa by my side memang 'di sisiku' atau 'di sampingku', bukan 'oleh sisiku' atau 'oleh sampingku'.

\section{e. Teknik Generalisasi}

Generalization atau generalisasi merupakan teknik penerjemahan yang menggunakan istilah atau ungkapan yang lebih umum dari terjemahan seharusnya. Hal ini bertepatan dengan acceptation milik SCFA dan merupakan kebalikan dari particularization atau pengkhusussan. Terdapat lima data yang masuk dalam kategori ini. Berikut adalah contoh teknik ini:

TSu: My eyes wanto to see what you see, ...

TSa: Aku ingin melihat yang engkau lihat, ...

Pada terjemahan ini, frasa my eyes yang bermakna 'mata saya', diterjemahkan oleh penerjemah malah secara lebih umum dengan hanya menerjemahakan 'aku' sebagai entitas utuh.

\section{f. Teknik Amplifikasi Linguistik}

Dari hasil penelitian, Linguistic Amplification atau Amplifikasi Linguistik muncul sebanyak delapan kali atau $3.83 \%$ dari total keseluruhan data. Teknik ini merupakan teknik yang menambahkan unsurunsur linguistik dalam terjemahannya. Hal ini sering digunakan pada penjurubahasaan konsekutif dan dubbing. Hal ini berlawanan dengan Linguistic compression. Contohnya dapat dilihat di bawah ini:

TSu: For every face I saw strange.

TSa: Setiap wajah yang aku lihat terlihat aneh.

Pada terjemahan di atas, penerjemah memberikan tambahan katan hubung 'yang' untuk menambahkan untuk memperjelas kalimat selanjutnya.

\section{g. Teknik Kompresi Linguistik}

Kompresi linguistik atau Linguistic Compression adalah teknik menyintesis unsur linguistik dalam TSa sehingga menjadi lebih singkat tanpa menghilangkan makna atau pesan yang ingin disampaikan. Hal ini biasa dilakukan dalam penjurubahasaan simultan dan sulih teks. Jenis ini berlawanan dengan amplifikasi linguistik. Contoh dari teknik ini yang ditemukan adalah sebagai berikut:

TSu: My eyes need to see what you see, my ears hear what you hear and my soul feel what you feel..
TSa: Aku ingin melihat yang engkau lihat, mendengar apa yang engkau dengar, merasakan apa yang kau rasa.

Pada terjemahan di atas, penerjemah tidak menerjemahkan kata demi kata teks sumbernya. Secara atauran tata bahasa, terdapat tiga klausa yang secara umum memiliki subjek yang sama sehingga penerjemah melakukan teknik kompresi linguistik dengan menghilangkan subjek pada klausa kedua dan ketiga.

\section{h. Teknik Modulasi}

Modulation atau modulasi merupkan teknik selanjutnya yang muncul dalam temuan penelitian. Sebanyak enam data terindikasi menjadi bagian dari teknik ini. Teknik modulasi merupakan teknik yang menerjemahakn dengan merubah sudut pandang, focus atau kategori kognitif dalam kaitannya dengan TSa. Modulasi ini dapat berupa leksikal atau structural. Jenis ini sama dengan acceptation. Contoh dari temuan teknik modulasi dapat dilihat sebagai berikut:

TSu: I had been presented with the truth about you.

TSa: Aku telah melihat kebenaran tentangmu.

Pada hasil terjemahan, terlihat bahwa subjek dalam kalimat adalah sebagai pelaku. Sedangkan pada TSu, subjek kalimat merupakan subjek yang dikenai pekerjaan tertentu, yaitu disajikan atau diberikan satu informasi berupa kebenaran tentang orang yang dituju dalam surat tersebut.

\section{i. Teknik Reduksi}

Teknik Reduction atau reduksi merupakan teknik yang bertujuan menekan item informasi TSu dalam TSa dengan menghilangkan unsur kata atau frasa dalam TSu. Reduksi meliputi implikasi dari SCFA dan Delisle, coincision dari Delisle, omission dari Vazquez Ayora. Jenis ini bertentangan dengan amplifikasi Contoh dari jenis teknik ini adlaah sebagai berikut:

TSu: Then at my darkest and loneliest moment...

TSa: Lalu di dalam gelap dan kesendirianku...

Dalam contoh data terjemahan di atas, penerjemah menghilangkan beberapa bagian dari teks sumber yaitu menghilangkan moment dan unsur 'paling' yang seharusnya kata gelap dan kesendirian adalah 'masa yang paling' atau superlative dari kondisinya.

\section{j. Teknik Transposisi}


Meskipun teknik transposition atau transposisi ini ditemukan cukup banyak dalam temuan, namun jumlahnya tidak sesignifikanteknik penerjemahan harfiah, yakni sebanyak 28 data atau $11 \%$ dari total keseluruhan data. Teknik transposisi ni merupakan teknik penerjemahan yang merubah kategori tata bahasa/gramatikal. Transposisi ini terbagi menjadi tiga yaitu transposisi struktur, unit, kategori (Mardiana, 2015) Contoh dari transposisi adalah sebagai berikut:

\section{1) Struktur}

\section{SL: My eyes need to see... \\ TL: Mata saya perlu melihat ...}

Contoh pada bagian ini menunjukkan adanya perubhana struktur menerangkan-diterangkan (MD) dalam TSu menjadi diterangkanmenerangkan (DM) dalam TSa.

\section{2) Unit}

$$
\begin{aligned}
& \text { SL: ...my ears want to hear what you hear... } \\
& \text { TL: ...telingaku ingin mendengar apa yang } \\
& \text { kamu dengar... }
\end{aligned}
$$

Pada data ini, terjadi transposisi unit. Transposisi ini dapat dilihat pada terjemahan frasa my ears. Pada TSu, my ears berbentuk frasa,dengan dua kata. Tapi pada terjemahannya menjadi satu kata saja dengan akhiran imbuhan $-\mathrm{ku}$.

\section{3) Kategori}

\section{SL: Last night $i$ had beautiful dream. \\ TL: Tadi malam aku bermimpi indah}

Dalam contoh terjemahan yang didapat dari temuan seperti di atas, kata dream pada TSu merupakan kata nomina. Namun dalam terjemahannya, kata tersebut berubah menjadi verba dengan terjemahannya 'bermimpi'.

\section{k. Teknik Variasi}

Variation atau variasi adalah teknik penerjemahan yang merubah unsur linguistik atau paralinguistik yang mempengaruhi aspek variasi linguistik: perubahan tone tekstual, gaya, dialek social, dialek geografis, dll., untuk mengenalkan atau mengubah indicator dialektikal untuk tokoh-tokoh saat menerjemahkan untuk teater, perubahan dalam tone untuk mengadaptasikan novel untuk anak-anak, dll. Contoh yang didapat dari temuan penelitian dapat dilihat sebagai berikut:
TSu: Please tell me how you feel.

TSa: Tolong beritahu saya bagaimana perasaan Anda

Pada temuan di atas, penerjemah melakukan teknik variasi (baik disengaja atau tidak). Jenis teks yang diterjemahkan adalah teks informal yang berupa surat cinta. Kata 'anda' yang digunakan sebagai terjemahan kata 'you' dalam surat cinta menjadikan kata tersebut menjadi kaku karena konteksnya buka situasi formal di mana biasanya kata 'Anda' dipakai terhadap lawan bicara.

\section{Temuan Lain}

Dalam penelitian ini, terdapat temuan lain, yaitu adanya dua atau lebih teknik penerjemahan yang digubakan dalam satu kalimat dan adanya galat dalam penerjemahan.

\section{a. Penggunaan Dua Atau Lebih Teknik Penerjemahan Dalam Satu Kalimat}

Dalam penelitian ini, peneliti menemukan berbagi data yang menunjukkan bahwa para penerjemah kerap melakukan dua atau lebih teknik penerjemahan dalam satu kalimat seperti contoh di bawah ini:

\section{TSu: For every face I saw strange.}

TSa: Setiap wajah yang kulihat aneh

Pada contoh temuan di atas,terdapat teknik reduksi dan amplifikasi linguistik dalam menerjemahkan 1 kalimat. Teknik reduksi didapat dari penghilngan kata 'for' yang tidak diterjemahakan. Sedangkan amplifikasi linguistik dilihat dari penambahan kata 'yang' sebagai kata hubung dari frasa 'yang kulihat' sebagai pemberi keterangan dari 'wajah' yang diterangkan.

\section{b. Galat dalam Terjemahan}

Terdapat galat yang terjadi oleh beberapa penerjemah yang menandakan kesalahan pemahaman kalimat dari TSu seperti contoh di bawah ini:

TSu: We were very happy.

TSa: Kami sungguh bahagia.

Dalam konteks yang ditulis di TSu, kata we merujuk pada si penulis dan kekasihnya yang menjadi tujuan tersebut ditujukan, atau lawan bicara dengan kata ganti 'you'. Oleh karena itu, kata we dalam TSu seharusnya diterjemahkan 'kita' dalam TSa, bukan 'kami'. 


\section{KESIMPULAN}

Penelitian ini menemukan bahwa tidak semua teknik penerjemahan dapat diterapkan dalam satu naskah terjemahan. Terlihat dalam penelitian ini bahwa hanya sebelas dari delapan belas teknik penerjemahan yang diterapkan oleh para penerjemah dengan tingkat kemampuan penerjemahan yang beragam. Keberagaman ini dapat dilihat dari banyaknya teknik yang digunakan oleh para penerjemah dalam menerjemahkan surat informal yang diberikan oleh peneliti.

Hal menarik yang terjadi adalah teknik penerjemahan harfiah menjadi sangat dominan dalam terjemahan yang dihasilkan. Hampir semua penerjemah menunjukkan kecenderungannya menggunkan teknik ini dengan jumlah data yang signifikan dibanding penggunaan teknik yang lain. Kecenderungan penggunaan penerjemahan harfiah ini didukung oleh sebaran distribusi data dengan kategori distribusi normal antara 17-27 data. Penerjemahan harfiah ini dapat menjadi terjemahan yang betul-betul menjadi terjemahan yang cukup memadai bagi 'disctribusi' pesan dari teks sumber ke teks sasaran atau bisa sekedar menerjemahkan tanpa memahami betul makna implisit yang ada di dalam teks sumber.

\section{REFERENSI}

Basnett, S. (2002). Translation Studies. In Year's Work in Critical and Cultural Theory (3rd ed.). https://doi.org/10.1093/ywcct/mbw001

Catford, J. . (1965). A Linguistic Theory of Translation. London: Oxford Univesity Press.

Gentzler, E. (2004). Contemporary Translation Theories. Shanghai: Shanghai Foreign Language Education Press.

Hidayat, A., \& Harmoko, D. D. (2018). Parafrasa dalam Terjemahan Novel Peebee Has A Wish. Retorika UNM, 11(1), 1-13. Retrieved from

http://ojs.unm.ac.id/retorika/article/view/4962 /pdf_16

JCPS. (2006). Letter Writing (F. Richardson, ed.). Retrieved from https://pdst.ie/sites/default/files/7590_Letter_
Writing_Book.pdf

Mardiana, W. (2015). Teknik Transposisi dan Modulasi: Kesepadanan dan Pergeseran dalam Penerjemahan Cerpen. PAROLE: Journal of Linguistics and Education, 4(2), 120-130.

https://doi.org/https://doi.org/10.14710/parole .v4i2\%20Oct.120-130

Molina, L., \& Albir, A. H. (2002). Translation techniques revisited: A dynamic and functionalist approach. Meta, 47(4), 498-512. https://doi.org/10.7202/008033ar

Mujiyanto, Y. (2011). Strategies in Translation Practices. In TLS - The Times Literary Supplement.

https://doi.org/10.2307/j.ctt9qh8h1.53

Nida, E. A., \& Taber, C. (1969). The Theory and Practice of Translation. Leiden: Brill.

Nord, C. (2007). Translating as a Purposeful Activity: Functionalist Approaches Explained. Manchester: St. Jerome Publishing.

Oettinger, A. G. (1960). Automatic Language Translation, Lexical and Technical Aspects, with Particular Reference to Russian. Cambridge: Harcard University Press.

Rahma, A., Kristina, D., \& Marmanto, S. (2018). Analisis Teknik Penerjemahan Adaptasi Dan Variasi Pada Subtitle Film Batman Versi Bahasa Jawa Mataraman. PRASASTI: Journal of Linguistics, $3(1), \quad 13$. https://doi.org/10.20961/prasasti.v3i1.19664

Shuping, R. (2013). Translation as Rewriting. International Journal of Humanities and Social Science, 3(18), 55-59. Retrieved from http://ijhssnet.com/journals/Vol_3_No_18_O ctober_2013/6.pdf

Wills, W. (1977). Übersetzungswissenschaft. Probleme und Methoden. In English translation as Translation Science. Problems and Methods. Tübingen: Narr.

Zhang, T. (2011). Politeness Principle in the Translation of Business Letters. Theory and Practice in Language Studies, 1(6), 615-621. https://doi.org/10.4304/tpls.1.6.615-621 